\title{
Acute and sub-acute toxicity study of a Pakistani polyherbal formulation
}

\author{
Saiqa Ishtiaq ${ }^{1 *}$, Maida Akram', Sairah Hafeez Kamran', Uzma Hanif ${ }^{2}$, Muhammad Shaharyar Khan Afridi ${ }^{1}$, \\ Sajid-ur-Rehman ${ }^{3}$, Atika Afzal ${ }^{1}$, Ayesha Asif ${ }^{4}$, Muhammad Younus ${ }^{3}$ and Shehla Akbar $^{5}$
}

\begin{abstract}
Background: Herbology is the prevailing system among the nationally-accepted alternative or complementary systems of medicine. The system is due to its general and patient-oriented methodology, is widely used in the general population exposing them to the risk of the side effects of the herbal medicines.

Method: The aim of study was to assess the acute and sub-acute toxicity of the polyherbal formulation Hab-eKabad Noshadri tablets. In the acute arm of the study, a single dose of $2000 \mathrm{mg} / \mathrm{kg}$ was administered to Swiss Albino mice which were observed for physical symptoms and behavioral changes for $72 \mathrm{~h}$. In sub-acute toxicity study repeated doses of the polyherbal preparation was administered to Wistar rats of both genders, separately. The animals received three doses of polyherbal product $(50 \mathrm{mg} / \mathrm{kg} / \mathrm{day}, 100 \mathrm{mg} / \mathrm{kg} / \mathrm{day}$ and $200 \mathrm{mg} / \mathrm{kg} / \mathrm{day}$ ) for a period of 28 days. On 28th day of experiment, blood sampling of animals was done for hematological and biochemical analysis i.e. liver and renal function parameters, lipid profile and then sacrificed for histopathological examination of liver and kidney.
\end{abstract}

Result: There was no morbidity and mortality noticed with single dose administration in acute toxicity study in mice. In sub-acute toxicity study, morphological changes with some damage in liver and kidney tissues of male and female animals were recorded at dose of $100 \mathrm{mg} / \mathrm{kg} /$ day and $200 \mathrm{mg} / \mathrm{kg} / \mathrm{day}$.

Conclusions: It was found that prolonged use at higher dose i.e. $200 \mathrm{mg} / \mathrm{kg} /$ day of this polyherbal formulation should be avoided and practitioners should cautiously prescribe this formulation in patients with hepatic and renal impairment.

Keywords: Toxicity studies, Polyherbal drug, Herbology, Acute toxicity, Sub-acute toxicity, Complementary medicine

\section{Background}

Herbal medicines are the most popular form of therapy for most of the world's population. A large number of population in the developing countries still rely on herbal medicine practitioners to meet their primary healthcare needs. The major reasons behind utilization of herbal medicines are that they are affordable, easily accessible, patient oriented and closely relates to patient's belief. This practice being natural and safe, perceived as non-toxic by the general population [1]. In the eighteenth century, when the medicinal therapy era was

\footnotetext{
* Correspondence: saiqa.pharmacy@pu.edu.pk

${ }^{1}$ Punjab University College of Pharmacy, University of the Punjab Allama lqbal Campus, Lahore 54000, Pakistan

Full list of author information is available at the end of the article
}

being introduced, the herbal treatment was the most preferred and available therapy. Many compounds from herbal origin have achieved widespread use as medicinal agents e.g. Taxols from Taxus baccata (English yew) as anticancer agents, Silibinin from Silybum marianum (Milk thistle) as liver tonic etc. [2-4]. The herbal therapy encompasses Ayurvedic, Naturopathic, Biochemical, Unani, Chinese, African and Native American medicine $[2,5]$. Herbal medicines have attained the widespread acceptability as natural therapeutic agents for various diseases like diabetes, arthritis, renal and liver diseases, obesity and cardiovascular disorders [6].

In contrast to the breakthrough of various conventional drugs from the studies of traditional cures and folk knowledge, a number of botanical drugs have proved to be very 
efficient in the management of various sicknesses. For example; Digitalis (Foxglove) as cardiotonic for heart failure, Catharanthus (Rozy periwinkle) as anticancer, Pilocarpus to treat dry mouth and glaucoma, Glycyrrhiza (liquorice) and Commiphora (Myrrh) for cough, Allium sativum (Garlic) as cholesterol lowering agent etc. [7, 8]. Around $70 \%$ of the local public relies totally on phytomedicines, they have clearly recurred into the setting as the need of the hour in primary healthcare [9]. Oriental herbology is mostly carried out, in which combination of different herbs are made to achieve maximum therapeutic outcomes than the individual herbs. These combinations are employed for the betterment of various chronic disorders [10-12] e.g. Diakyur, (polyherbal drug) employed in the management of type II diabetes, contains seven herbal materials [13]. Similarly, Soshiho-tang, consist of seven herbs, is an oriental herbal formula used in Japan, China and Korea. It possesses various pharmacological actions that includes; antioxidant, anti-inflammatory, immunomodulatory, anti-hepatic fibrotic, hepatoprotective, and antitumoral effects [14].

The pharmacological aspects and properties of these drugs have been studied, by various researchers in different laboratories, extensively. In addition to this, conventional people and even still certain physicians invoke the usage of medicinal and curative herbs which are well documented with scientific evidences, to aid the medication therapy for better clinical outcomes but their selection is limited not only due to concerns of pharmaceutical quality but also in terms of their safety profile and toxicity index [15]. In spite of huge usefulness of these herbal remedies, there are certain limitations to their use. There is a lack of data on their safety and toxicity index. Certain toxicity studies has captured the attention and compelled the researchers to work and evaluate the safety spectrum of these phytomedicines $[16,17]$.

The test preparation is one of a renowned polyherbal natural formulation in Pakistan. The product label claims it to be an effective medicine for the treatment of hepatitis, enlargement of liver (hepatomegaly), liver function disorders, dyspepsia (indigestion), flatulence (abdominal gas), abdominal pain, nausea, vomiting, lack of appetite, constipation and carminative. The dose of the formulation as claimed by the label is $3 \mathrm{~g} /$ day for adults and $1.5 \mathrm{~g} /$ day for children [18]. As the exact duration of use and the side effects of the product is not mentioned on the label, we designed this study to assess the safety profile and toxicity index of the polyherbal formulation for a specific period of time.

\section{Methods}

Herbal product

The Hab-e-Kabad Noshadri tablets is a product of Qarshi Industries (Pvt.) Ltd. The product contains Ammonium chloride (17.55 mg), Black salt (17.55 mg), Common salt $(\mathrm{NaCl})$ (17.55 mg), Lake salt (17.55 mg), Zedoary (Curcuma zedoaria) (17.55 mg), Sodium borate (17.55 mg), Ginger (Zingiber officinale) (17.55 mg), Chebulicmyrobalan black (Terminalia chebula) (17.55 mg), Embelia (Embelia ribs) (17.55 mg), Rose (Rosa indica) (17.55 mg), Belericmyrobalan (Terminalia belerica) (17.55 mg), Black pepper (Piper nigrum) (17.55 mg), Senna leaflets (Cassia angustifolia, Cassia acutifolia) (17.55 mg), and Chebulicmyrobalan yellow (Terminalia chebula) (35.10 mg).

\section{Experimental animals}

Young healthy Swiss albino mice (both sexes), 5-6 weeks old, weighing about 24-25 g and Wistar rats (both sexes), 9-12 weeks old weighing about 150-200 g were used in this study. The animals were purchased from University of Veterinary and Animal Sciences Lahore, Pakistan. The animals were maintained under standard environmental conditions $\left(23-25{ }^{\circ} \mathrm{C}, 12 \mathrm{~h} / 12 \mathrm{~h}\right.$ light/dark cycle) and had free access to standard pelleted diet, water ad libitum. Animals were acclimatized to laboratory environment for a week prior to start study. The protocol used in this study was approved by the Animal Ethical Committee of Punjab University College of Pharmacy (AEC/UCP/1043), prepared by National Institute of Health.

\section{Experimental design \\ Dose calculation}

The different doses selected for the toxicity study were chosen on the basis of the claim of the polyherbal formulation label (3 g/day for adults). The $50 \mathrm{mg} / \mathrm{kg} /$ day was selected according to the dose employed in adult human beings on daily bases. Higher doses (100 and $200 \mathrm{mg} / \mathrm{kg} /$ day) were selected for sub-acute toxicity study. The dose of the individual rats in all different groups was calculated based on the body weights before the start of the study.

\section{Acute toxicity study test}

Mice were fasted for $24 \mathrm{~h}$ prior to the commencement of this test. Ten animals (mice); five males and five females were used and each animal were given a single dose of $2000 \mathrm{mg} / \mathrm{kg}$ of Polyherbal product (p.o.). Animals were observed strictly and individually for first $30 \mathrm{~min}$ after dosing and periodically during first $24 \mathrm{~h}$. (with special attention during first $4 \mathrm{~h}$ ) and daily thereafter for 3 days. Mice were observed for altered autonomic effects (lacrimation, salivation, piloerection), central nervous system effect (tremors, convulsion, drowsiness) skin (fur), body weight, food consumption, water consumption and mortality [19]. 


\section{Sub-acute toxicity study}

Forty Wistar rats were divided into 4 groups of 10 each (5 males \& 5 females). Three groups of experimental doses $50 \mathrm{mg} / \mathrm{kg} /$ day, $100 \mathrm{mg} / \mathrm{kg} /$ day and $200 \mathrm{mg} / \mathrm{kg} /$ day respectively and the forth group was of control. Control group was fed with only normal food and water. Animals were weighed weekly and observed for behavioral changes, food and water consumption, and general morphological changes. On the 28 th day of treatment period, animals were anaesthetized by i.p. administration of $5 \mathrm{ml} / \mathrm{kg}$ of a solution of $1 \%$ chloralose in $25 \%$ urethane $(w / v)$. Blood samples were collected from rats by cardiac puncture into EDTA sample tubes for hematological analysis and into heparinized tubes for serum generation for biochemical analysis. Serum was acquired after allowing blood to congeal for $30 \mathrm{~min}$. And centrifugation. After sacrificing the experimental animals, vital organs including; kidneys and Liver were harvested, carefully examined [20]. The offcuts of the organs were conserved for histopathological assessment. Mortality in each treatment group was recorded during the course of the 28 day administration of the product.

\section{Hematological analysis}

Blood samples were analyzed by using established procedures and the $\mathrm{CBC}$ machine by Medonic. Parameters evaluated include; WBCs count, RBCs count, PLT count, $\mathrm{Hb}, \mathrm{HCT}, \mathrm{MCV}, \mathrm{MCH}$ and $\mathrm{MCHC}$.

\section{Biochemical parameters}

Serum samples were analyzed for creatinine, blood urea, uric acid, TG, cholesterol, HDL, VLDL, bilirubin, AST and ALT by using instrument Junior Series.

\section{Histopathological assessment}

Liver and kidney tissues were obtained from experimental animals and fixed in 10\% formol-saline. Later, these tissues were dehydrated in graded alcohol, inserted in paraffin, and cut into $4-5 \mu \mathrm{m}$ thick sections. Hematoxylin-eosin was used to stain the sections for photomicroscopic assessment using a Model N-400ME photomicroscope. Slides were examined using the 40X, and 100X objectives [21, 22].

\section{Statistical analysis}

Results are communicated as mean \pm SEM. Data analysis was carried out using One-way ANOVA with posthoc Tukey's HSD test. For weight variation, Two-way ANOVA with post-hoc Dunnett's test was applied for multiple comparisons (SPSS 21). Significance was measured at values of $p<0.05$ and $p<0.01$.

\section{Results}

\section{Acute toxicity study}

In acute toxicity testing, all animals were observed carefully for development of any toxic signs or symptoms at different time intervals of $0,30 \mathrm{~min}, 1,2,4,6,8,12 \mathrm{~h}$. and then daily for a period of 3 days. There was no toxic signs observed in clinical parameters during acute study. So, it indicates that the $\mathrm{LD}_{50}$ of the polyherbal formulation is greater than $2000 \mathrm{mg} / \mathrm{kg} /$ day BW (Table 1).

\section{Sub-acute toxicity study}

The study was conducted for four weeks (28 days) with three different doses; $50 \mathrm{mg} / \mathrm{kg} /$ day, $100 \mathrm{mg} / \mathrm{kg} /$ day, $200 \mathrm{mg} / \mathrm{kg} /$ day and one group treated as control. The parameters focused were body weight, food and water consumption, hematological parameters (WBCs, RBCs, $\mathrm{PLT}, \mathrm{Hb}, \mathrm{HCT}, \mathrm{MCH}, \mathrm{MCV}$, and $\mathrm{MCHC}$ ), liver function parameters (Bilirubin, ALT, AST), renal function profile

Table 1 Acute study with dose of $2000 \mathrm{mg} / \mathrm{kg} /$ day on male and female mice for three days

\begin{tabular}{|c|c|c|c|c|c|c|c|c|c|c|c|}
\hline \multirow[t]{2}{*}{ Sr. No. } & \multirow[t]{2}{*}{ Parameters } & \multicolumn{10}{|l|}{ Animals } \\
\hline & & Male 1 & Male 2 & Male 3 & Male 4 & Male 5 & Female 1 & Female 2 & Female 3 & Female 4 & Female 5 \\
\hline 1 & Lacrimation & No & No & No & No & No & No & No & No & No & No \\
\hline 2 & Salivation & No & No & No & No & No & No & No & No & No & No \\
\hline 3 & Piloerection & No & No & No & No & No & No & No & No & No & No \\
\hline 4 & Drowsiness & No & No & No & No & No & No & No & No & No & No \\
\hline 5 & Tremors & No & No & No & No & No & No & No & No & No & No \\
\hline 6 & Convulsions & No & No & No & No & No & No & No & No & No & No \\
\hline 7 & Fur & Normal & Normal & Normal & Normal & Normal & Normal & Normal & Normal & Normal & Normal \\
\hline 8 & Body weight & $23 \mathrm{~g}$ & $23 \mathrm{~g}$ & $25 \mathrm{~g}$ & $25 \mathrm{~g}$ & $27 \mathrm{~g}$ & $23 \mathrm{~g}$ & $22 \mathrm{~g}$ & $23 \mathrm{~g}$ & $24 \mathrm{~g}$ & $24 \mathrm{~g}$ \\
\hline 9 & Food consumption & Normal & Normal & Normal & Normal & Normal & Normal & Normal & Normal & Normal & Normal \\
\hline 10 & water consumption & Normal & Normal & Normal & Normal & Normal & Normal & Normal & Normal & Normal & Normal \\
\hline 11 & Mortality & No & No & No & No & No & No & No & No & No & No \\
\hline
\end{tabular}




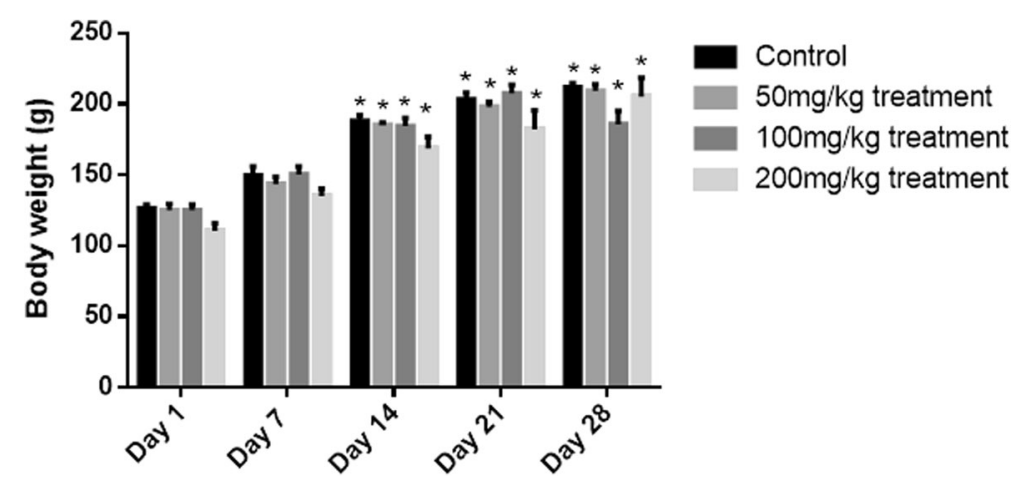

Fig. 1 Body weight variation of control and treated male rats during sub-acute toxicity studies. The data is presented as mean \pm SEM. Two-way ANOVA was used for multiple comparisons by applying Dunnett's test and the weights of all the groups were compared with their relevant weight on Day 1. * represents significance of $p<0.05$

(blood urea, creatinine, and uric acid), and lipid profile (triglycerides, cholesterol, HDL, VLDL).

\section{Effect on body weight}

Weight variations of both male and female treated and control groups were noted. A gradual raise in the weights of male rats throughout the sub-acute study. There was a significant increase in the weights observed from day 14 till the end of the study in all treatment groups in comparison to their relevant weights on day 1 (Fig. 1). Whereas, for females a different pattern was observed. The graphical representation shows that at the start of the study the body weights of the treated groups were normal, no significant change in the weight was observed till day 14 as compared to their relevant weights on day 1 . On day 21 there was a significant increase in weight of control, 50 and $100 \mathrm{mg} / \mathrm{kg} /$ day treatment groups but there was not any marked change for treatment group of $200 \mathrm{mg} / \mathrm{kg} /$ day. While on day 28, all groups i.e. control, 100 and $200 \mathrm{mg} / \mathrm{kg} /$ day except $50 \mathrm{mg} / \mathrm{kg} /$ day showed significant changes in weights for female rats (Fig. 2).

\section{Clinical signs}

Nasal bleeding was observed on 17th and 18th day at dose of $200 \mathrm{mg} / \mathrm{kg} /$ day in both male and female rats. Paralysis in the right upper paw in both male and female group was observed 15 days after the treatment during sub-acute study at dose of $200 \mathrm{mg} / \mathrm{kg} /$ day (Table 2).

\section{Effect on hematological parameters}

The Hematological result shows that WBCs count of male animal of treatment dose of $100 \mathrm{mg} / \mathrm{kg} /$ day raise significantly and highly significantly for $200 \mathrm{mg} / \mathrm{kg} /$ day as that of control group. RBCs count was normal with all treatment groups as that of control. PLT count with treatment doses of $50 \mathrm{mg} / \mathrm{kg} /$ day and $100 \mathrm{mg} / \mathrm{kg} /$ day didn't show any significant variation with that of control but with dose of $200 \mathrm{mg} / \mathrm{kg} /$ day PLT count showed highly significant increase with that of control. Hemoglobin value for dose of $200 \mathrm{mg} / \mathrm{kg} /$ day declined

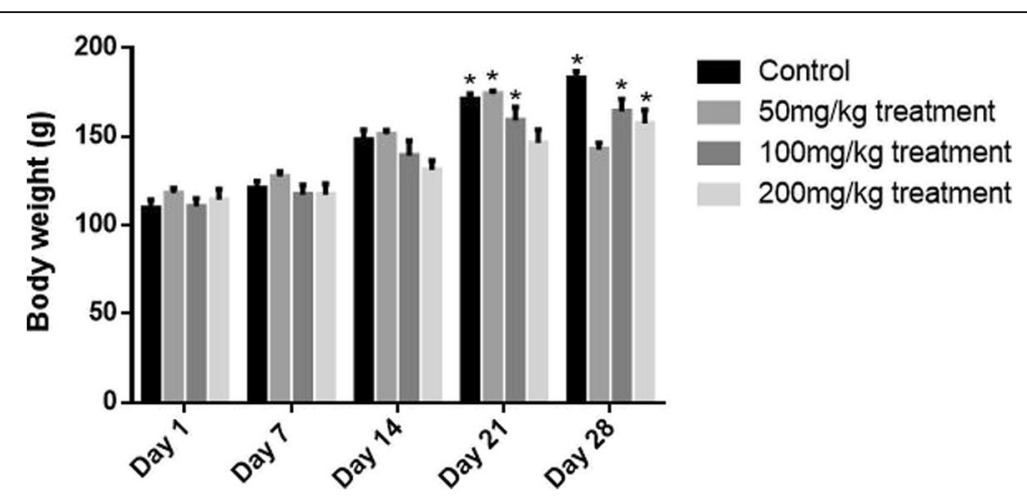

Fig. 2 Body weight variation of control and treated female rats during sub-acute toxicity studies. The data is presented as mean \pm SEM. Two-way ANOVA was used for multiple comparisons by applying Dunnett's test and the weights of all the groups were compared with their relevant weight on Day 1. * represents significance of $p<0.05$ 
Table 2 Observations of physical signs during sub-acute toxicity study

\begin{tabular}{|c|c|c|c|c|c|c|c|c|}
\hline \multirow[t]{2}{*}{ Parameters } & \multicolumn{4}{|l|}{ Males } & \multicolumn{4}{|l|}{ Females } \\
\hline & Control & 50 mg/kg/day & 100 mg/kg/day & 200 mg/kg/day & Control & 50 mg/kg/day & 100 mg/kg/day & $200 \mathrm{mg} / \mathrm{kg} / \mathrm{day}$ \\
\hline Nasal bleeding & - & - & - & + & - & - & - & + \\
\hline Paralysis & - & - & - & + & - & - & - & + \\
\hline
\end{tabular}

$n=5,-=$ absence of the clinical signs, $+=$ presence of the clinical signs

significantly as compared to control while remained near to control for rest of the treatment groups. HCT, MCV, $\mathrm{MCH}, \mathrm{MCHC}$ remained normal. The Hematological estimation of female rats of all treatment doses and control group shows that there is no significant change in all parameters of complete blood count, but only the PLT count with the treatment dose of $200 \mathrm{mg} / \mathrm{kg} /$ day showed highly significant decrease with that of control but within the normal range [23] (Table 3; Additional file 1).

\section{Effect on biochemical parameters Liver parameters}

The liver parameters of male and female rats of all treatment doses groups showed that the levels of ALT and AST declined highly significantly as compared to control at dose of $200 \mathrm{mg} / \mathrm{kg} /$ day. Though with dose 50 and $100 \mathrm{mg} / \mathrm{kg} /$ day, the liver enzymes were near to the lower normal range as compared to the control group (Table 4).

\section{Kidney parameters}

Kidney parameters of male and female rats of both treatment and control groups showed that blood urea of the drug with dose of $50 \mathrm{mg} / \mathrm{kg} /$ day remained almost same as that of control. While the blood urea with the treatment doses of $100 \mathrm{mg} / \mathrm{kg} /$ day and $200 \mathrm{mg} / \mathrm{kg} /$ day were raised highly significantly with that of control but remained in the normal range. Creatinine level of male rats with dose of $50 \mathrm{mg} / \mathrm{kg} /$ day rose highly significantly with that of control but was in normal range while remained same with the treatment doses $100 \mathrm{mg} / \mathrm{g} / \mathrm{day}$ and $200 \mathrm{mg} / \mathrm{kg} /$ day as that of control group. While, creatinine level of female rats with dose of $50 \mathrm{mg} / \mathrm{kg} / \mathrm{day}$ rose highly significantly with that of control while with the treatment dose of $100 \mathrm{mg} / \mathrm{kg} /$ day didn't show any change with that of control group and with dose of $200 \mathrm{mg} / \mathrm{kg} /$ day the creatinine level significantly decreased as that of control group. Result shows that uric acid level of male rats treatment doses of $50 \mathrm{mg} / \mathrm{kg} /$ day and $100 \mathrm{mg} / \mathrm{kg} /$ day has declined highly significantly but remained in the normal range as that of control but the treatment dose of $200 \mathrm{mg} / \mathrm{kg} /$ day remained almost same with that of control. On the other hand, in the female rats the uric acid level of treatment dose of $50 \mathrm{mg} / \mathrm{kg} /$ day didn't show any noteworthy change with that of control group and with doses of $100 \mathrm{mg} / \mathrm{kg} /$ day and $200 \mathrm{mg} / \mathrm{kg} /$ day increased highly significantly as that of control (Table 5).

\section{Lipid profile}

The result of lipid profile of male rat treatment groups and control group shows that triglyceride level of treatment dose $200 \mathrm{mg} / \mathrm{kg} /$ day of the drug increased significantly as compared to control while in rest of the treatment doses the level remained close to the control. The cholesterol level of treatment doses of $50 \mathrm{mg} / \mathrm{kg} /$ day and $100 \mathrm{mg} / \mathrm{kg} /$ day showed highly significant increase with that of control group and treatment dose of

Table 3 Effect of different test doses of product on hematological parameters in male \& female rats

\begin{tabular}{|c|c|c|c|c|c|c|c|c|}
\hline \multirow[t]{2}{*}{ Parameters } & \multicolumn{4}{|l|}{ Males } & \multicolumn{4}{|l|}{ Females } \\
\hline & Control & 50 mg/kg/day & 100 mg/kg/day & 200 mg/kg/day & Control & 50 mg/kg/day & 100 mg/kg/day & 200 mg/kg/day \\
\hline $\begin{array}{l}\text { WBCs } \\
\left(10^{*} 3 / \mathrm{ul}\right)\end{array}$ & $4.91 \pm 0.245$ & $4.97 \pm 0.141$ & $5.79^{*} \pm 0.144$ & $6.14^{* *} \pm 0.143$ & $2.642 \pm 0.137$ & $3.102 \pm 1.090$ & $3.350 \pm 1.174$ & $3.232 \pm 1.128$ \\
\hline $\begin{array}{l}\text { RBCs } \\
\left(10^{*} 6 / u l\right)\end{array}$ & $6.80 \pm 0.178$ & $6.33 \pm 0.152$ & $7.18 \pm 0.141$ & $6.28 \pm 0.212$ & $7.596 \pm 0.83$ & $7.214 \pm 0.210$ & $7.870 \pm 0.197$ & $7.544 \pm 0.227$ \\
\hline $\begin{array}{l}\text { PLT } \\
\left(10^{*} 3 / \mathrm{ul}\right)\end{array}$ & $643.804 \pm 2.429$ & $644.09 \pm 1.432$ & $644.496 \pm 1.373$ & $654.26^{* *} \pm 1.314$ & $682.582 \pm 1.928$ & $675.50 \pm 1.496$ & $683.794 \pm 1.941$ & $667.068^{* *} \pm 1.594$ \\
\hline $\mathrm{Hb}(\mathrm{g} / \mathrm{dl})$ & $12.028 \pm 0.218$ & $12.038 \pm 0.166$ & $11.076 \pm 0.143$ & $10.972^{*} \pm 0.306$ & $12.55 \pm 0.240$ & $12.66 \pm 0.278$ & $13.156 \pm 0.306$ & $13.052 \pm 0.370$ \\
\hline HCT (\%) & $40.066 \pm 0.437$ & $40.422 \pm 0.338$ & $40.172 \pm 0.473$ & $39.962 \pm 0.337$ & $38.276 \pm 0.395$ & $37.696 \pm 0.505$ & $38.726 \pm 0.433$ & $38.33 \pm 0.561$ \\
\hline $\mathrm{MCV}(\mathrm{fl})$ & $76.020 \pm 0.443$ & $75.456 \pm 0.432$ & $75.728 \pm 0.362$ & $75.582 \pm 0.310$ & $74.302 \pm 0.440$ & $73.822 \pm 0.532$ & $73.926 \pm 0.850$ & $75.094 \pm 0.820$ \\
\hline $\mathrm{MCH}(\mathrm{pg})$ & $20.788 \pm 0.454$ & $20.396 \pm 0.289$ & $20.242 \pm 0.336$ & $20.332 \pm 0.371$ & $21.716 \pm 0.535$ & $21.168 \pm 0.295$ & $21.048 \pm 0.325$ & $21.168 \pm 0.567$ \\
\hline $\mathrm{MCHC}(\mathrm{g} / \mathrm{dl})$ & $40.368 \pm 0.400$ & $40.610 \pm 0.244$ & $40.544 \pm 0.237$ & $40.468 \pm 0.355$ & $41.142 \pm 0.358$ & $41.574 \pm 0.527$ & $41.404 \pm 0.621$ & $41.126 \pm 0.452$ \\
\hline
\end{tabular}

The data are expressed as mean and standard error of the mean $(n=5)$. For statistical analysis one-way ANOVA with post-hoc Tukey's test was applied.

* represents significance of $p<0.05,{ }^{* *}$ represents significance of $p<0.01$ 
Table 4 Effect of different test doses of product on bilirubin, ALT and AST in male and female rats

\begin{tabular}{|c|c|c|c|c|c|c|c|c|}
\hline \multirow[t]{2}{*}{ Parameters } & \multicolumn{4}{|l|}{ Males } & \multicolumn{4}{|l|}{ Females } \\
\hline & Control & $\begin{array}{l}50 \\
\mathrm{mg} / \mathrm{kg} / \text { day }\end{array}$ & $\begin{array}{l}100 \\
\mathrm{mg} / \mathrm{kg} / \text { day }\end{array}$ & $\begin{array}{l}200 \\
\mathrm{mg} / \mathrm{kg} / \text { day }\end{array}$ & Control & $\begin{array}{l}50 \\
\mathrm{mg} / \mathrm{kg} / \mathrm{day}\end{array}$ & $\begin{array}{l}100 \\
\mathrm{mg} / \mathrm{kg} / \text { day }\end{array}$ & $\begin{array}{l}200 \\
\mathrm{mg} / \mathrm{kg} / \text { day }\end{array}$ \\
\hline Bilirubin (mg/dl) & $1.575 \pm 0.051$ & $0.592^{* *} \pm 0.011$ & $0.602^{* *} \pm 0.010$ & $0.696^{* *} \pm 0.013$ & $1.0 \pm 0.063$ & $0.64^{* *} \pm 0.045$ & $0.76 \pm 0.045$ & $1.56^{* *} \pm 0.060$ \\
\hline $\operatorname{ALT}(\mu / m l)$ & $38.42 \pm 0.229$ & $8.4^{* *} \pm 0.172$ & $8.86^{* *} \pm 0.141$ & $6.942^{* *} \pm 0.102$ & $38.47 \pm 0.309$ & $9.54^{* *} \pm 0.454$ & $9.41^{* *} \pm 0.383$ & $9.28^{* *} \pm 0.311$ \\
\hline AST $(\mu / m l)$ & $39.9 \pm 0.251$ & $10.0^{* *} \pm 0.254$ & $8.68^{* *} \pm 0.154$ & $8.62^{* *} \pm 0.261$ & $37.92 \pm 0.419$ & $10.98^{* *} \pm 0.503$ & $9.54^{* *} \pm 0.310$ & $8.98^{* *} \pm 0.661$ \\
\hline
\end{tabular}

The data are expressed as mean and standard error of the mean $(n=5)$. For statistical analysis one-way ANOVA with post-hoc Tukey's test was applied. * represents significance of $p<0.05,{ }^{* *}$ represents significance of $p<0.01$

$200 \mathrm{mg} / \mathrm{kg} /$ day showed highly significant decrease with that of control. HDL value with all treatment groups highly significantly decreased with that of control. VLDL value was normal with that of control with doses of $50 \mathrm{mg} / \mathrm{kg} /$ day and $100 \mathrm{mg} / \mathrm{kg} /$ day while with dose of $200 \mathrm{mg} / \mathrm{kg} /$ day VLDL value increased highly significantly. In case of females, animals showed that triglyceride level of treatment doses of $50 \mathrm{mg} / \mathrm{kg} /$ day and $200 \mathrm{mg} / \mathrm{kg} /$ day increased highly significantly with that of control but remained in safe range. With treatment dose of $100 \mathrm{mg} / \mathrm{kg} /$ day of the drug the triglyceride level remained in the range of control group. The cholesterol level of treatment dose of $50 \mathrm{mg} / \mathrm{kg} /$ day didn't show any significant change with that of control. With dose of $100 \mathrm{mg} / \mathrm{kg} /$ day the cholesterol level raised highly significantly as compared to control group. With the higher treatment dose of $200 \mathrm{mg} / \mathrm{kg} /$ day the cholesterol level decreased highly significantly as compared to the control group. HDL value with all treatment groups highly significantly decreased with that of control. VLDL value was normal with that of control with doses of $50 \mathrm{mg} / \mathrm{kg} /$ day and $100 \mathrm{mg} / \mathrm{kg} /$ day. While, with dose of $200 \mathrm{mg} / \mathrm{kg} /$ day VLDL value increased highly significantly. All lipid profiles of male and female rats showed that the values were either significantly increased or decreased but remained within the normal range (Table 6).

\section{Histopathological examination of organs Kidney}

The normal distill and proximal tubule along with glomerulus was observed in the slides of male and female rats of control group (Figs. 3 and 4). The histopathological examination of kidney of male and female rats with dose of $50 \mathrm{mg} / \mathrm{kg} /$ day showed same symmetry of cells as that of control groups (Figs. 5 and 6) but with doses of $100 \mathrm{mg} / \mathrm{kg} /$ day (Figs. 7 and 8) and $200 \mathrm{mg} / \mathrm{kg} /$ day (Figs. 9 and 10) showed infiltration of WBCs and RBCs, presented damage in kidney structures of both male and female rats.

\section{Liver}

The histopathological examination of liver of both male and female rats with distil water (Figs. 11 and 12) normal structures. The sections with dose of $50 \mathrm{mg} / \mathrm{kg} /$ day showed normal structures as that of control group with slight inflammation of portal vein and infiltration of inflammatory cells (Figs. 13 and 14). Male and female rat groups with dose of $100 \mathrm{mg} / \mathrm{kg} /$ day showed presence of inflammatory cells and congestion of sinusoids (Figs. 15 and 16), with the subsequent high dose of $200 \mathrm{mg} / \mathrm{kg} /$ day, the treatment groups showed the inflammatory cells penetration near central vein and destruction of pattern of sinusoids with congestion of hepatocytes and dilation of sinusoids (Figs. 17 and 18).

\section{Discussion}

Polyherbal formulations are abundantly used in developed countries as compared to allopathic medicine for the treatment of different types of ailments [24]. In Pakistan Hab e Kabad Noshadri tablets, are effectively employed for the treatment of gastric and hepatic ailments. In this study acute and sub-acute toxicity of herbal product was analyzed in male and female Swiss Albino mice and Wistar rats, respectively. The acute

Table 5 Effect of different test doses of product on blood urea, creatinine and uric acid in male and female rats

\begin{tabular}{|c|c|c|c|c|c|c|c|c|}
\hline \multirow[t]{2}{*}{ Parameters } & \multicolumn{4}{|l|}{ Males } & \multicolumn{4}{|l|}{ Females } \\
\hline & Control & $\begin{array}{l}50 \\
\mathrm{mg} / \mathrm{kg} / \text { day }\end{array}$ & $\begin{array}{l}100 \\
\mathrm{mg} / \mathrm{kg} / \text { day }\end{array}$ & $\begin{array}{l}200 \\
\mathrm{mg} / \mathrm{kg} / \text { day }\end{array}$ & Control & $\begin{array}{l}50 \\
\mathrm{mg} / \mathrm{kg} / \text { day }\end{array}$ & $\begin{array}{l}100 \\
\mathrm{mg} / \mathrm{kg} / \text { day }\end{array}$ & $\begin{array}{l}200 \\
\mathrm{mg} / \mathrm{kg} / \text { day }\end{array}$ \\
\hline $\begin{array}{l}\text { Blood urea } \\
(\mathrm{mg} / \mathrm{dl})\end{array}$ & $23.6 \pm 0.265$ & $23.7 \pm 0.432$ & $28.7^{* *} \pm 0.355$ & $31.4^{* *} \pm 0.966$ & $22.98 \pm 0.323$ & $24.50 \pm 0.295$ & $28.75^{* *} \pm 0.439$ & $38.22^{* *} \pm 0.461$ \\
\hline $\begin{array}{l}\text { Creatinine } \\
(\mathrm{mg} / \mathrm{dl})\end{array}$ & $0.494 \pm 0.029$ & $0.686^{* *} \pm 0.020$ & $0.472 \pm 0.036$ & $0.428 \pm 0.042$ & $0.40 \pm 0.029$ & $0.652^{* *} \pm 0.027$ & $0.44 \pm 0.022$ & $0.29^{*} \pm 0.004$ \\
\hline $\begin{array}{l}\text { Uric acid } \\
(\mathrm{mg} / \mathrm{dl})\end{array}$ & $3.476 \pm 0.035$ & $2.14^{* *} \pm 0.223$ & $2.4^{* *} \pm 0.041$ & $3.36 \pm 0.137$ & $3.44 \pm 0.035$ & $3.42 \pm 0.033$ & $3.98^{* *} \pm 0.033$ & $4.06^{* *} \pm 0.045$ \\
\hline
\end{tabular}

The data are expressed as mean and standard error of the mean $(n=5)$. For statistical analysis one-way ANOVA with post-hoc Tukey's test was applied. * represents significance of $p<0.05,{ }^{* *}$ represents significance of $p<0.01$ 
Table 6 Effect of different test doses of product on TG, Cholesterol, HDL and VLDL in male and female rats

\begin{tabular}{|c|c|c|c|c|c|c|c|c|}
\hline \multirow[t]{2}{*}{ Parameters } & \multicolumn{4}{|l|}{ Males } & \multicolumn{4}{|l|}{ Females } \\
\hline & Control & $\begin{array}{l}50 \\
\mathrm{mg} / \mathrm{kg} / \text { day }\end{array}$ & $\begin{array}{l}100 \\
\mathrm{mg} / \mathrm{kg} / \text { day }\end{array}$ & $\begin{array}{l}200 \\
\mathrm{mg} / \mathrm{kg} / \text { day }\end{array}$ & Control & $\begin{array}{l}50 \\
\mathrm{mg} / \mathrm{kg} / \text { day }\end{array}$ & $\begin{array}{l}100 \\
\mathrm{mg} / \mathrm{kg} / \text { day }\end{array}$ & $\begin{array}{l}200 \\
\mathrm{mg} / \mathrm{kg} / \text { day }\end{array}$ \\
\hline TG & $40.4 \pm 0.312$ & $41.2 \pm 0.845$ & $38.6 \pm 0.460$ & $70.08^{* *} \pm 1.234$ & $40.64 \pm 0.456$ & $44.65^{* *} \pm 0.344$ & $42.72 \pm 0.248$ & $72.38^{* *} \pm 0.733$ \\
\hline Cholesterol & $68.54 \pm 0.275$ & $80.1^{* *} \pm 0.604$ & $74.72^{* *} \pm 0.426$ & $57.68^{* *} \pm 0.303$ & $72.06 \pm 0.580$ & $74.01 \pm 0.269$ & $74.88^{* *} \pm 0.620$ & $68.24^{* *} \pm 0.412$ \\
\hline $\mathrm{HDL}$ & $37.04 \pm 0.394$ & $33.96^{* *} \pm 0.356$ & $22.42^{* *} \pm 0.290$ & $25.12^{* *} \pm 0.386$ & $38.72 \pm 0.210$ & $35.28^{* *} \pm 0.397$ & $28.1^{* *} \pm 0.304$ & $15.64^{* *} \pm 0.221$ \\
\hline VLDL & $6.13 \pm 0.259$ & $6.14 \pm 0.225$ & $6.16 \pm 0.263$ & $10.86^{* *} \pm 0.190$ & $5.86 \pm 0.145$ & $5.96 \pm 0.128$ & $5.94 \pm 0.158$ & $10.96^{* *} \pm 0.121$ \\
\hline
\end{tabular}

The data are expressed as mean and standard error of the mean $(n=5)$. For statistical analysis one-way ANOVA with post-hoc Tukey's test was applied. * represents significance of $p<0.05, * *$ represents significance of $p<0.01$

toxicity study was conducted for $72 \mathrm{~h}$. at the dose of $2000 \mathrm{mg} / \mathrm{kg} /$ day, no morbidity and mortality was observed. This proves that the drug could be safely administered for acute treatments up to the dose of $2000 \mathrm{mg} /$ $\mathrm{kg} /$ day.

During the sub-acute toxicity study non-significant changes in hematological and biochemical parameters of liver, lipids and renal markers were observed with $50 \mathrm{mg} / \mathrm{kg} /$ day and $100 \mathrm{mg} / \mathrm{kg} /$ day depicting that these doses could be safely employed for the treatment of liver disorders as claimed by the label. The label claims presence of Embelia and Senna as an ingredients in the formulation that have proved to be effective in liver disorders $[25,26]$. The formulation also contain chebulicmyrobalan yellow (Terminalia chebula), that has phenolic content which inhibits phenotype change in HSC in liver and reduces the infiltration of neutrophils in the liver and protecting liver from inflammational damage [27], as observed at dose of $50 \mathrm{mg} / \mathrm{kg} /$ day during sub-acute study. The formulation also contains

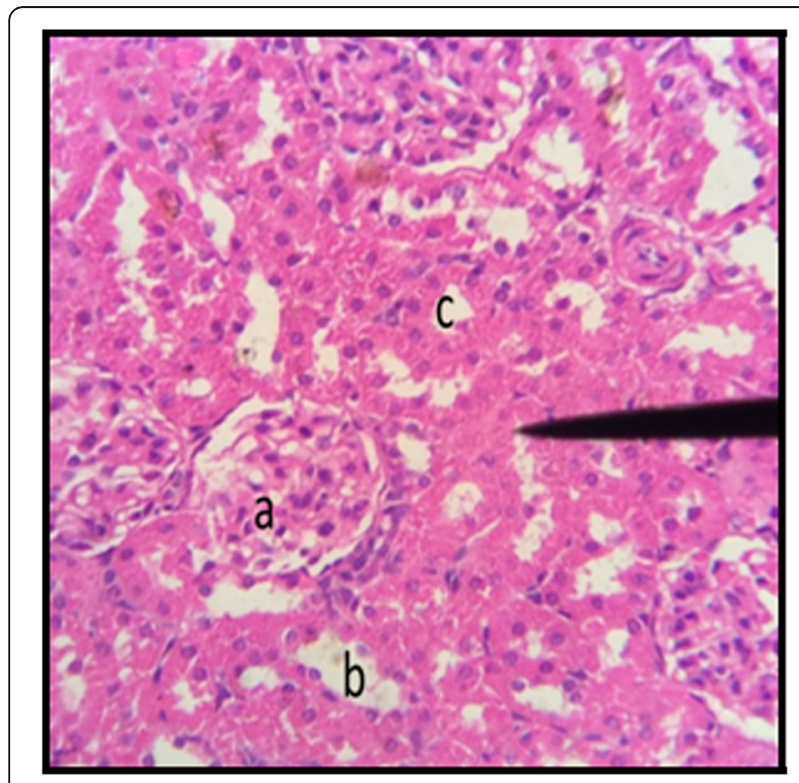

Fig. 3 Kidney Section of Male Rat (Control) X400. a normal glomerulus of control male rat, $\mathbf{b}$ normal distal tubules, $\mathbf{c}$ normal proximal tubules zedoary (Curcuma zedoaria), ginger (Zingiber officinale), senna leaflets (Cassia angustifolia, Cassia acutifolia), belericmyrobalan (Terminalia belerica), black pepper (Piper nigrum), and chebulicmyrobalan yellow (Terminalia chebula) reported to possess anti-inflammatory actions. These drugs have been reported to possess different types of flavonoids, therefore exhibiting antiinflammatory actions when given in combination [2734]. Belericmyrobalan (Terminalia belerica) inhibits the inflammatory mediators and chemotactic cytokines (TNFo and IL-6) and decreases inflammatory reactions [35]. Black pepper (Piper nigrum), contains piperine responsible for antioxidant anti-inflammatory action that hinders in many signaling pathways that may involve in the proliferation of T-lymphocytes and thus protecting body from many chronic inflammatory diseases [36]. The formulation also contains chebulicmyrobalan black (Terminalia chebula) analyzed by researcher, possessing kidney protective action [37] also proved in our study at dose of $50 \mathrm{mg} / \mathrm{kg} /$ day and the results are presented in

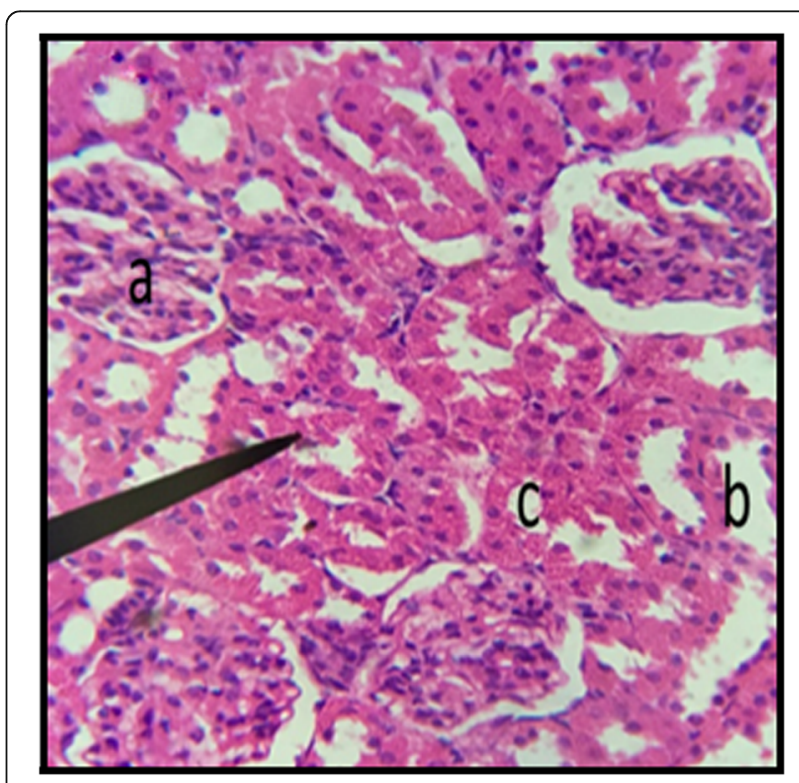

Fig. 4 Kidney Section of Female Rat (Control) X400. a normal glomerulus, b normal distal tubule, $\mathbf{c}$ normal proximal tubule 


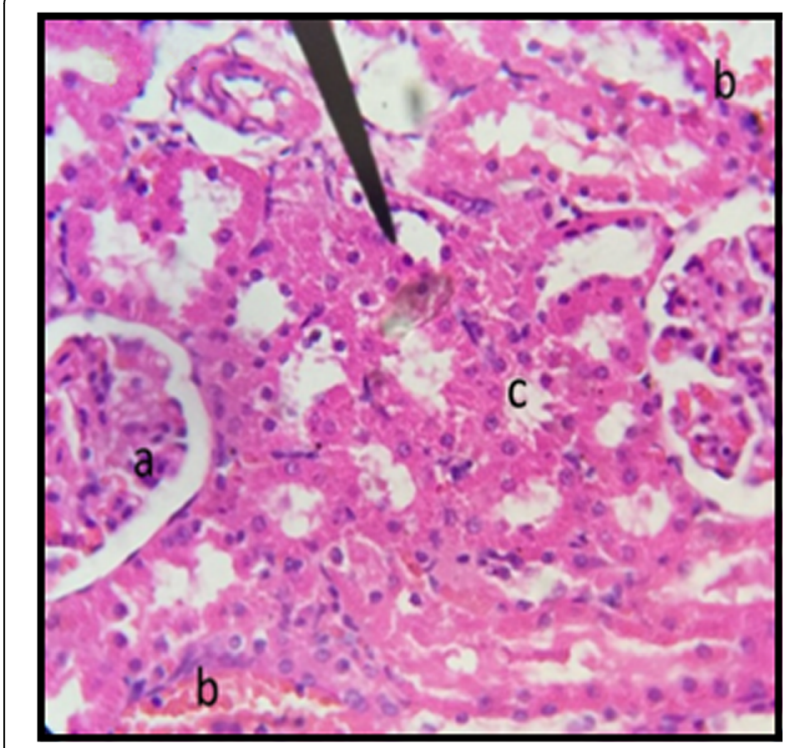

Fig. 5 Kidney Section of Male Rat (50 mg/kg/day) X400. a normal glomerulus, $\mathbf{b}$ little bit dilation of peritubular capillaries, $\mathbf{c}$ normal proximal tubule

Table 4. Embelia (Embelia ribs) has strong ability on dyslipidemia associated with hypercholesterolemia. It reduces cholesterol and TG levels [38] at dose of $50 \mathrm{mg} / \mathrm{kg} /$ day presented in Table 5. Belericmyrobalan (Terminalia belerica) increases body weight and decreases serum cholesterol, triglycerides, uric acid and creatinine [39] that was also observed during sub-acute toxicity study at dose of $50 \mathrm{mg} / \mathrm{kg} /$ day in both male and female rats (Figs. 1 and 2).

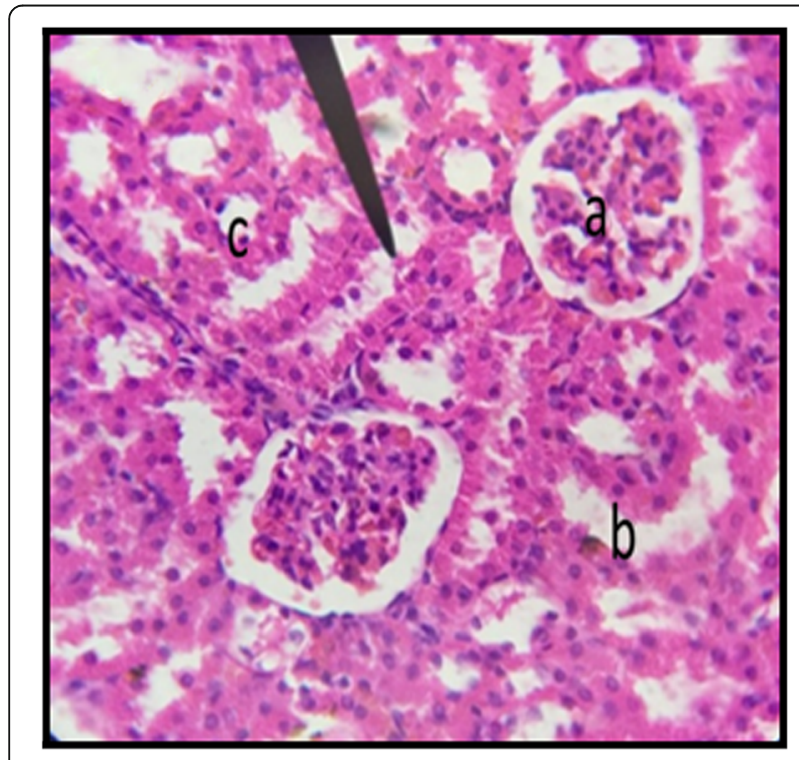

Fig. 6 Kidney Section of Female Rat (50 mg/kg/day) X400. a normal glomerulus, b normal distal tubule, $\mathbf{c}$ normal proximal tubule

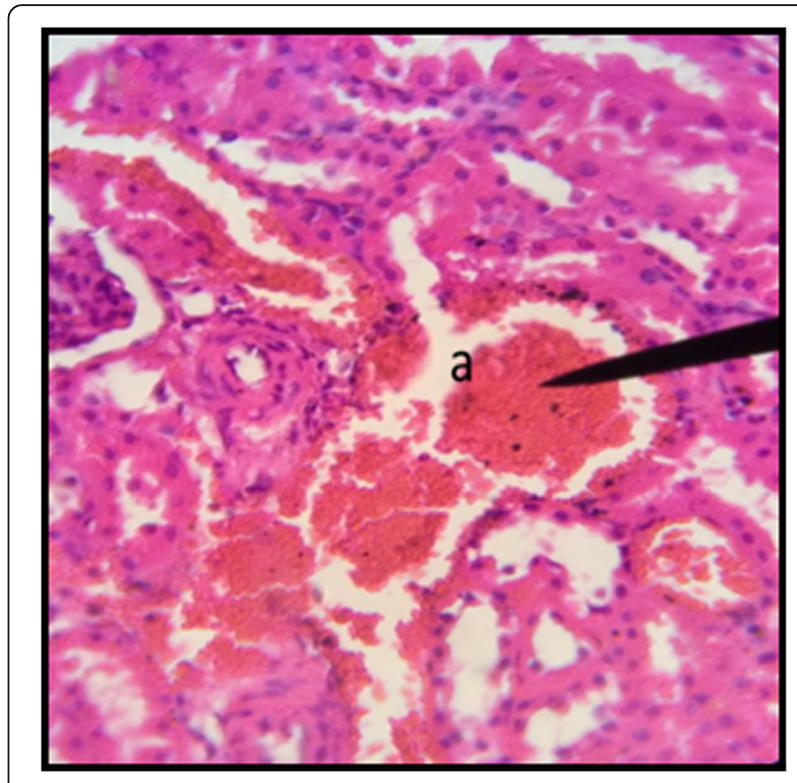

Fig. 7 Kidney Section of Male Rat (100 mg/kg/day) X400. a coalescence of capillaries along with damage to the glomerulus

In the histopathalogical examination no changes in liver and kidney morphology were seen at dose of $50 \mathrm{mg} / \mathrm{kg} /$ day whereas, congestion with mild inflammation was observed due to the infiltration of neutrophils in the liver with $100 \mathrm{mg} / \mathrm{kg} /$ day. The kidney's histopathological examination also showed coalescence of capillaries with the infiltration of RBCs suggesting that the dose of $100 \mathrm{mg} / \mathrm{kg} /$ day should be cautiously prescribed by the

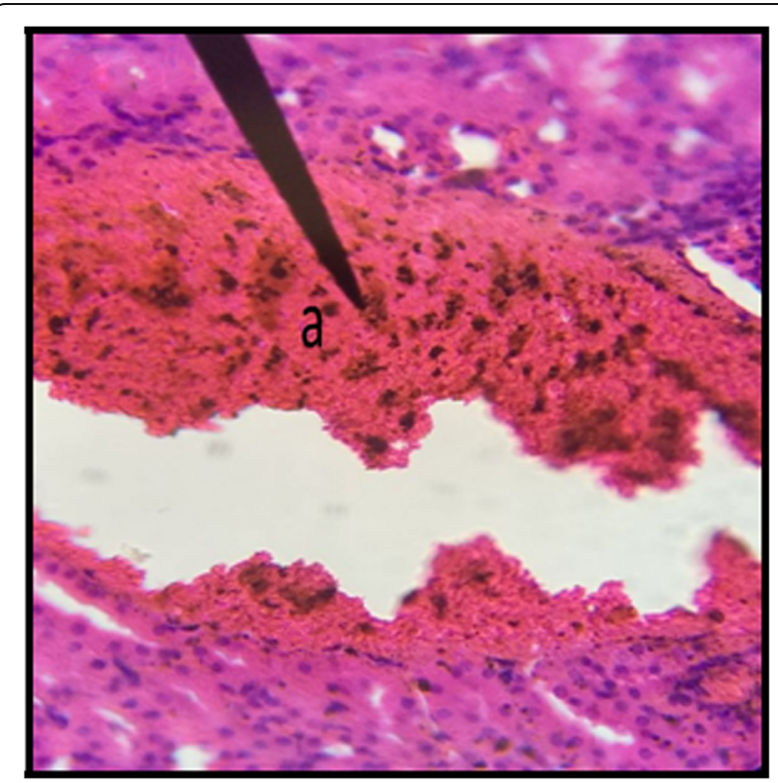

Fig. 8 Kidney Section of Female Rat (100 mg/kg/day) X400. a damage to nephron along with infiltration of RBCs 


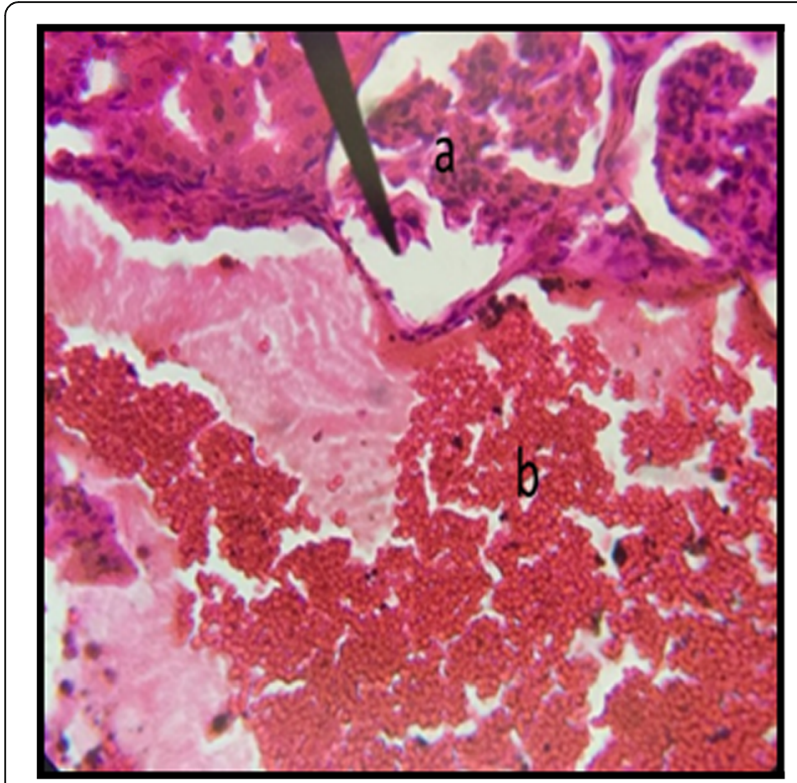

Fig. 9 Kidney Section of Male Rat (200 mg/kg/day) X400. a normal glomerulus, $\mathbf{b}$ rupture of the basement membrane along with the infiltration of blood cells

practitioners. However, no change in the biochemical parameters was observed during sub-acute study but the structural changes at $100 \mathrm{mg} / \mathrm{kg} /$ day suggests that the product is more appropriate to be prescribed at dose of $50 \mathrm{mg} / \mathrm{kg} /$ day.

During the sub-acute toxicity studies, a significant decrease in the liver enzymes with $200 \mathrm{mg} / \mathrm{kg} /$ day was observed in both male and female rats and this decrease was below the normal reference range. The bilirubin

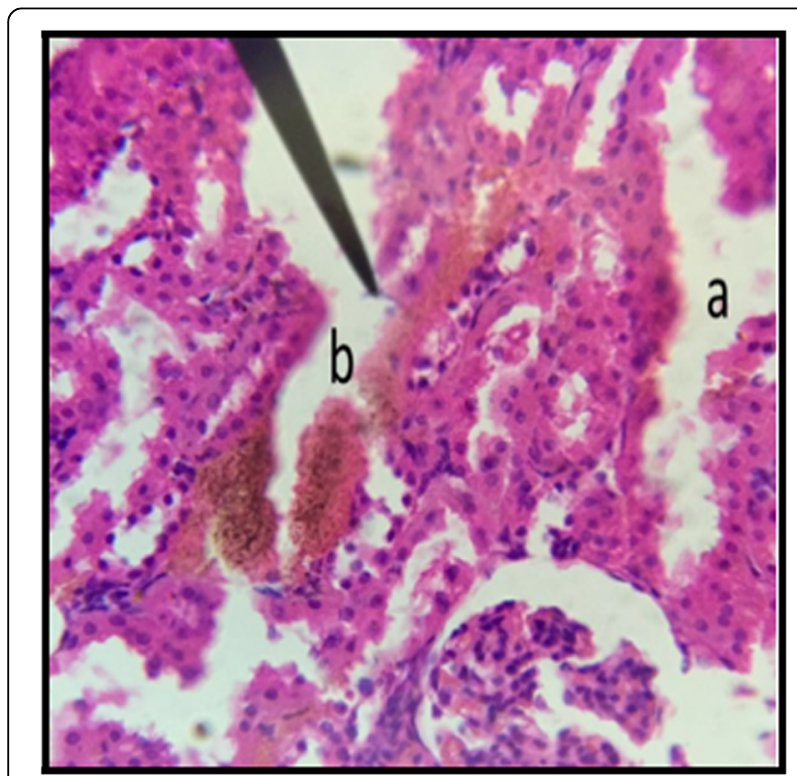

Fig. 10 Kidney Section of Female Rat ( $200 \mathrm{mg} / \mathrm{kg} /$ day $)$ X400. a congestion of the nephrons, $\mathbf{b}$ infiltration of the inflammatory cells

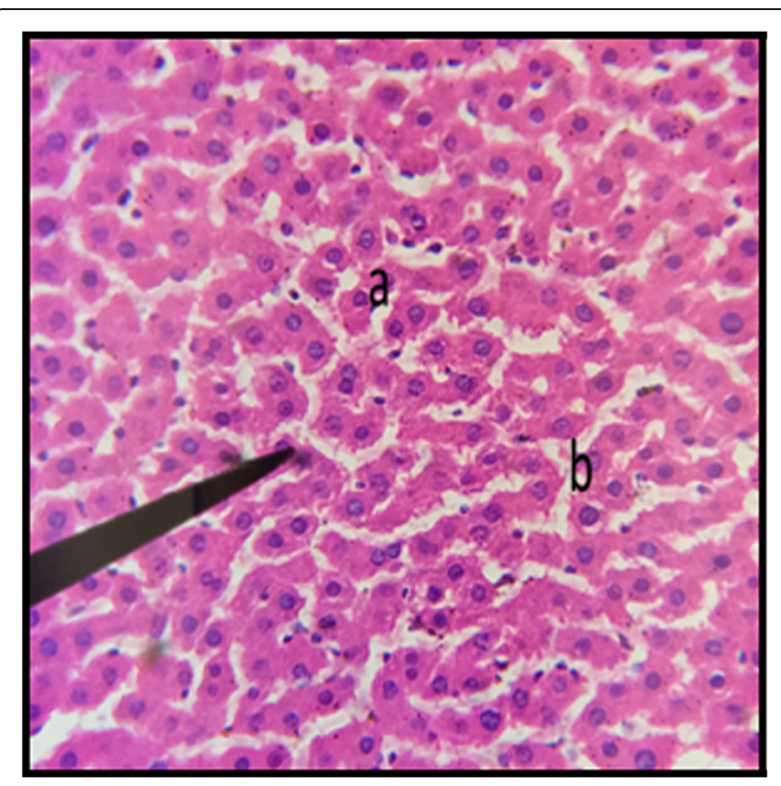

Fig. 11 Liver Section of Male Rat (Control) X400. a normal sinusoids, b central vein, c: portal vein

levels were also significantly raised in female rats. It was due to the non-functional behavior of the hepatocytes in the liver that happened due to the coalescence of the hepatocytes. In the histopathological observation of liver the shrinkage (atrophy) and fusion of the hepatocytes was observed (Figs. 17 and 18), and the highly significant $(p<0.01)$ decrease in the liver enzymes (Table 5) suggests that $200 \mathrm{mg} / \mathrm{kg} /$ day should not be prescribed. The physical abnormalities viz. nasal bleeding on 17th and 18th day and right upper paw

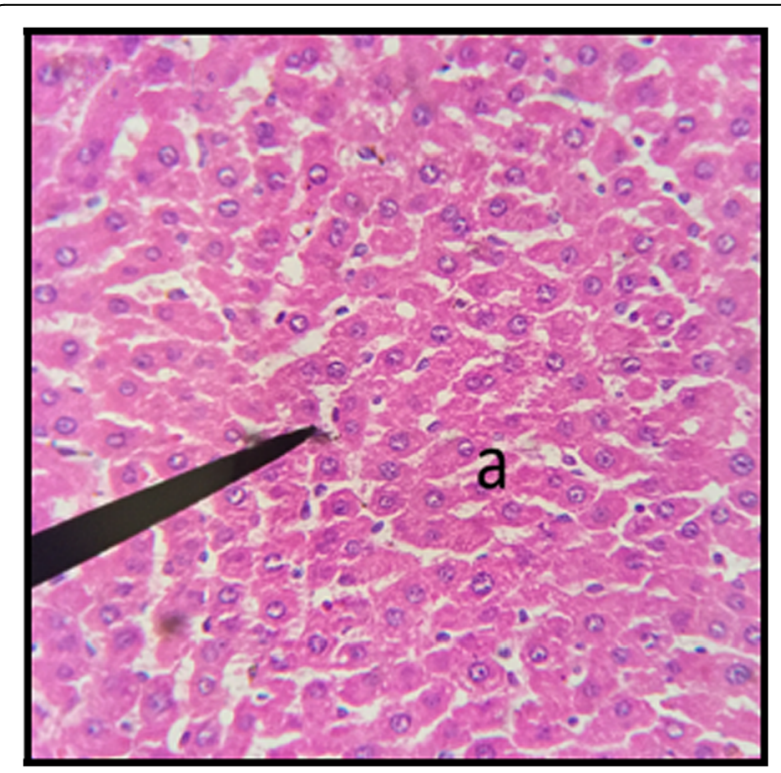

Fig. 12 Liver Section of Female Rat (Control) X400. a normal sinusoids and hepatocytes 


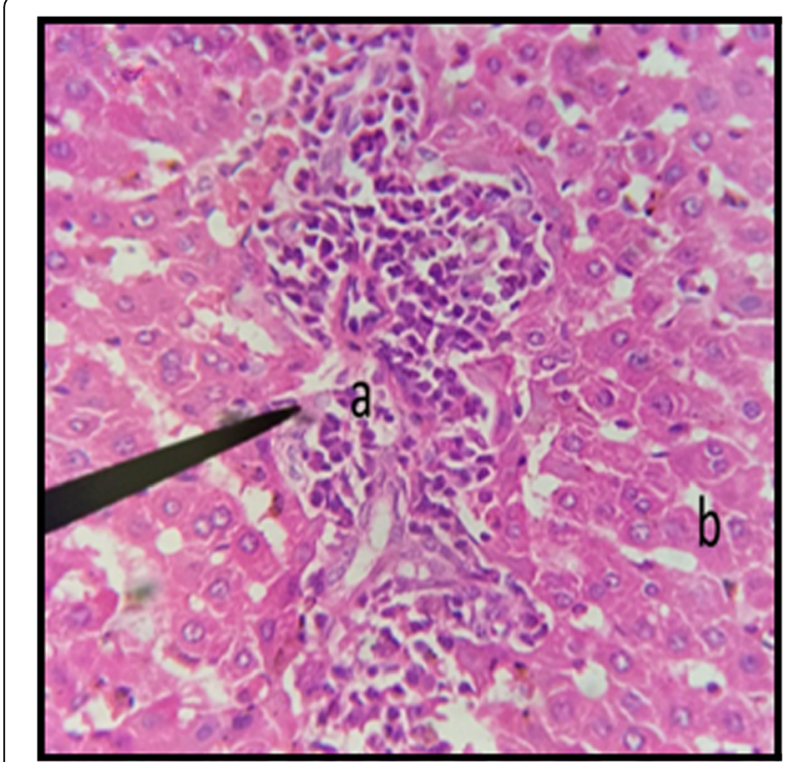

Fig. 13 Liver Section of Male Rat (50 mg/kg/day) X400. a inflammation in portal vein, $\mathbf{b}$ normal sinusoids

paralysis after 15 days of treatment was also observed during the sub-acute study. The nasal bleeding may be due to the decreased synthesis of plasma proteins by the destructed liver that are responsible for the clotting $[40,41]$. Liver damage also results into portal hypertension which consequently shows the complication of bleeding due to the raised pressure [42]. Similarly, the compromising renal and ESRD also results in hemostatic disorders mainly in the form of

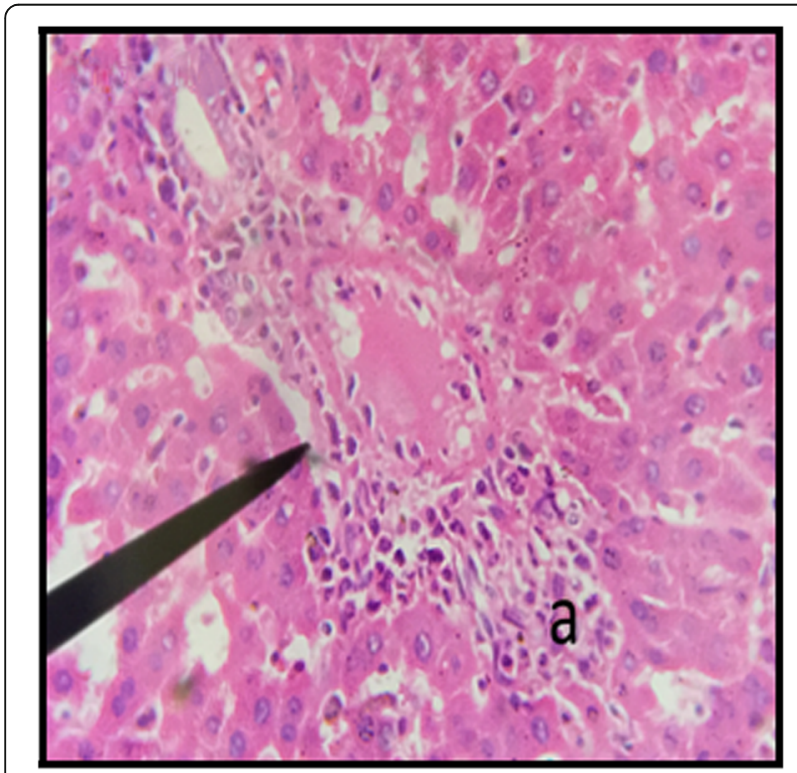

Fig. 14 Liver Section of Female Rat (50 mg/kg/day) X400. a infiltration of inflammatory cells in sinusoidal spaces

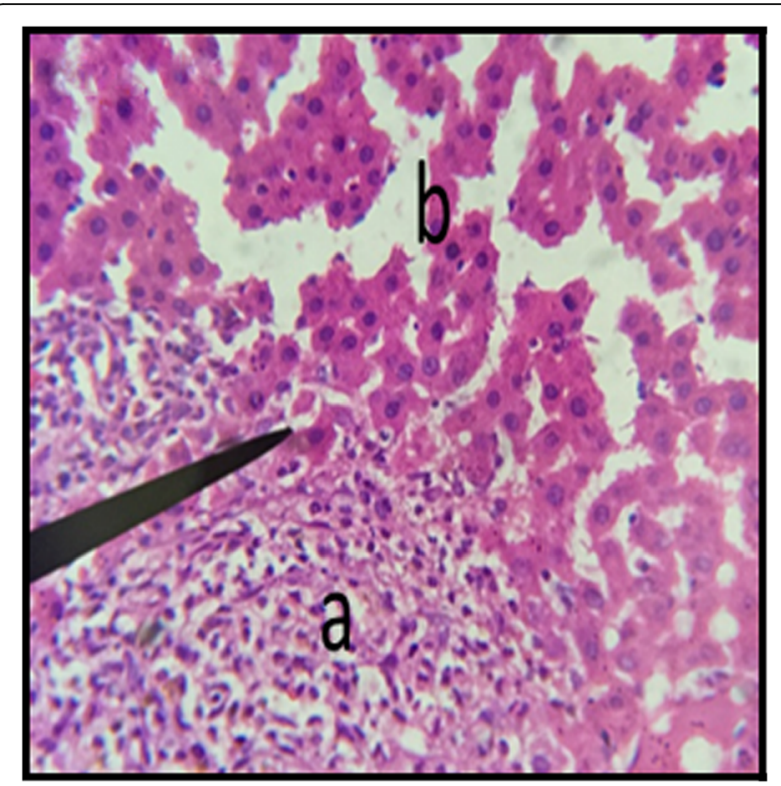

Fig. 15 Liver Section of Male Rat (100 mg/kg/day) X400. a presence of inflammatory cells, $\mathbf{b}$ congestion of sinusoids

bleeding diatheses [43]. On the other hand the right upper paw paralysis may be due to the neurodegenerative action of the formulation in the specific part of brain controlling the right upper paw of the test subjects. These clinical signs suggests that $200 \mathrm{mg} / \mathrm{kg} /$ day is not safe to be prescribed by the healthcare providers. The levels of urea were significantly increased in both male and female rats, uric acid was also significantly raised in female treated group.

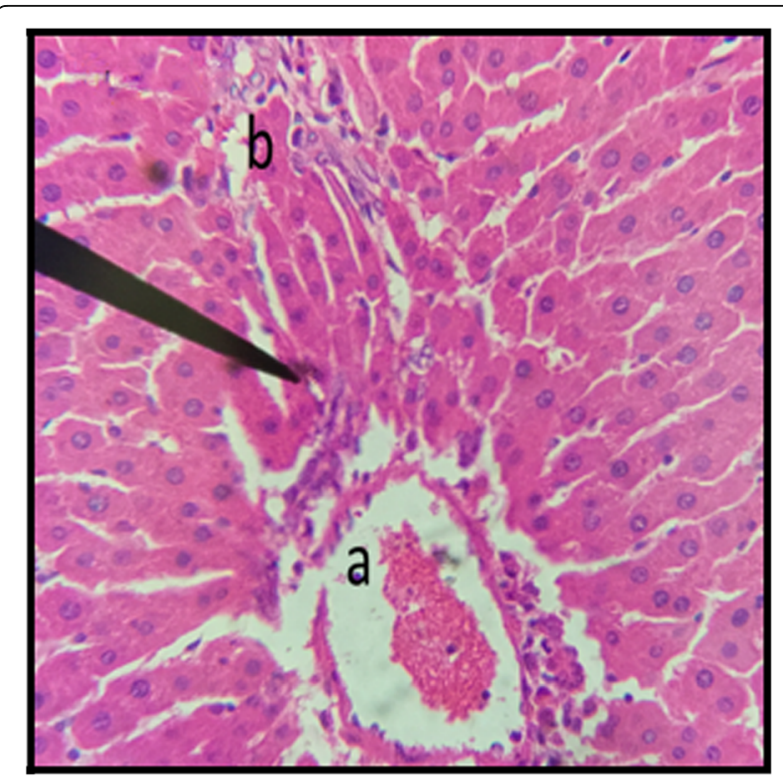

Fig. 16 Liver Section of Female Rat (100 mg/kg/day) X400. a inflammation of central vein, $\mathbf{b}$ inflammation surrounding central vein 


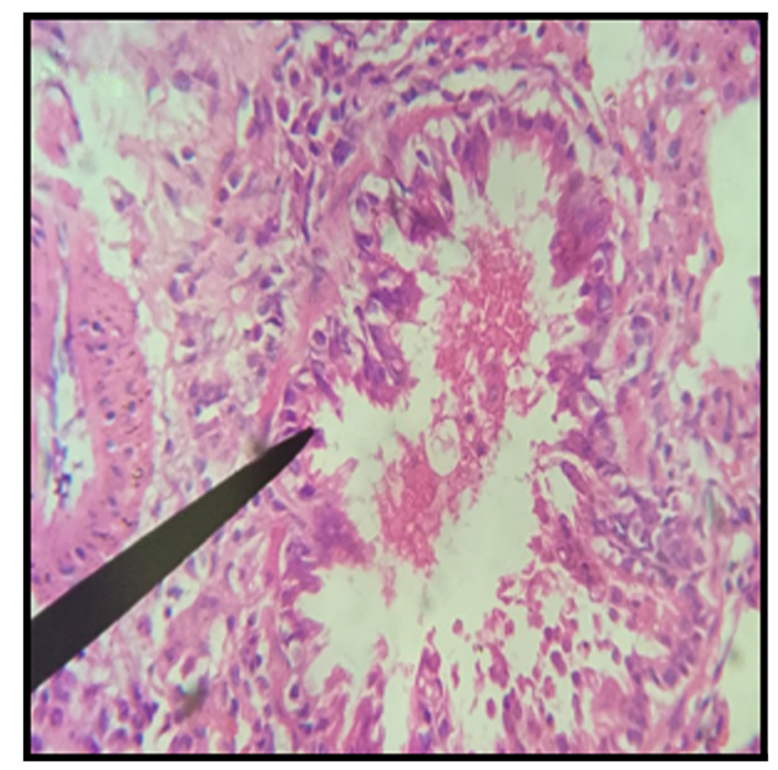

Fig. 17 Liver Section of Male Rat (200 mg/kg/day) X400. a infiltration of inflammatory cells in central vein, $\mathbf{b}$ destructive sinusoids

Uremia (increased urea in blood) and hyperurecemia (increased uric acid in blood) indicates the nephrotoxic potential of the formulation at dose of $200 \mathrm{mg} /$ $\mathrm{kg} /$ day. The histopathological examination of the kidney also showed damage (Figs. 9 and 10) to the nephrons suggesting that prolonged use of formulation may result into CKD. The levels of TG and VLDL were increased in both male and female rats whereas,

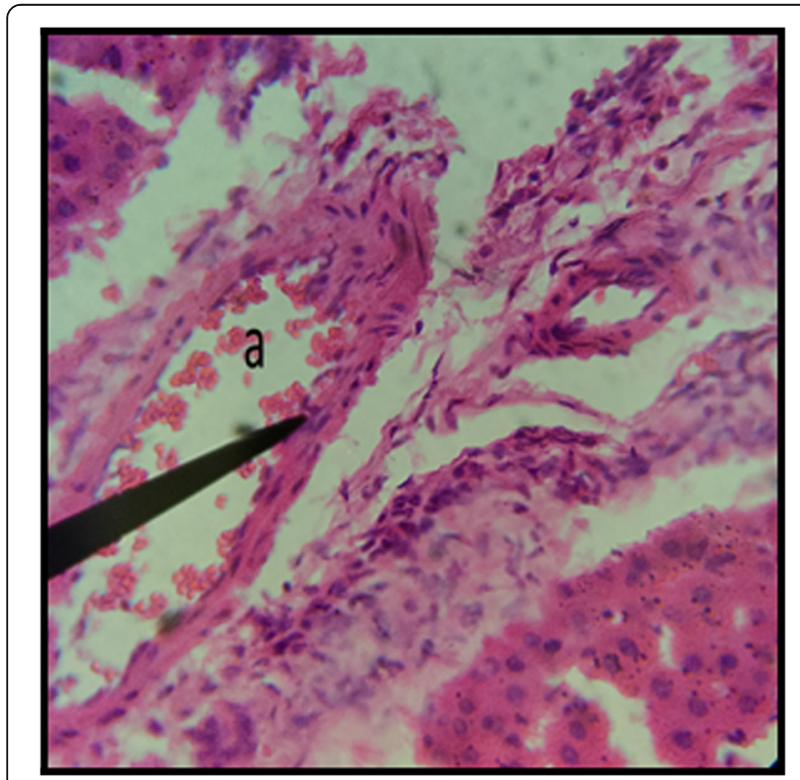

Fig. 18 Liver Section of Female Rat (200 mg/kg/day) X400. a congestion of hepatocytes
HDL was significantly decreased suggesting disorders in lipid metabolism which may lead to cardiovascular diseases. Significant increase in the WBCs and PLT count with 100 and $200 \mathrm{mg} / \mathrm{kg} /$ day also proves that these doses result into an increase in the inflammatory burden. It could be suggested that oriental herbalogy may result into interactions or toxicity on prolong use, when given in higher doses.

\section{Conclusions}

The findings of acute study revealed that this polyherbal formulation is non-toxic with single oral dose of $2000 \mathrm{mg} / \mathrm{kg} /$ day. The 28 days sub-acute toxicity study, revealed no significant changes with $50 \mathrm{mg} / \mathrm{kg} /$ day. Slight changes in biochemical parameters and structural levels was at $100 \mathrm{mg} / \mathrm{kg} /$ day and severe cellular changes at $200 \mathrm{mg} / \mathrm{kg} / \mathrm{day}$. So, it is concluded that the formulation is safe to use at dose of $50 \mathrm{mg} / \mathrm{kg} /$ day for a period of 28 days whereas the $100 \mathrm{mg} / \mathrm{kg} /$ day should be cautiously employed and $200 \mathrm{mg} / \mathrm{kg} /$ day should not be recommended. In future it is recommended to analyze the effects of the individual ingredients on the organs and tissues at different doses.

\section{Supplementary material}

The doses are converted according to the following chart [44] Table 7.

Dose $1=50 \mathrm{mg} / \mathrm{kg} /$ day.

Dose for $0.15 \mathrm{~kg}$ rat $=50 \times 0.15=7.5 \mathrm{mg} / 0.15 \mathrm{~kg}$.

Conversion into Human equivalent dose $(\mathrm{HED})=7.5 \times 0.162=1.215 \mathrm{mg} / \mathrm{kg}$.

Dose for $60 \mathrm{~kg}$ (Avg.) human $=1.215 \times 60=72.9 \mathrm{mg} /$ $60 \mathrm{~kg}$ man $\approx 75 \mathrm{mg} / 60 \mathrm{~kg}$.

Dose $2=100 \mathrm{mg} / \mathrm{kg} /$ day.

Dose for $0.15 \mathrm{~kg}$ rat $=100 \times 0.15=15 \mathrm{mg} / 0.15 \mathrm{~kg}$.

Conversion into Human equivalent dose $(\mathrm{HED})=15 \times 0.162=2.43 \mathrm{mg} / \mathrm{kg}$.

Dose for $60 \mathrm{~kg}$ (Avg.) human $=2.43 \times 60=145.8 \mathrm{mg} /$ $60 \mathrm{~kg}$ man $\approx 150 \mathrm{mg} / 60 \mathrm{~kg}$.

Dose $3=200 \mathrm{mg} / \mathrm{kg} /$ day.

Dose for $0.15 \mathrm{~kg}$ rat $=200 \times 0.15=30 \mathrm{mg} / 0.15 \mathrm{~kg}$.

Conversion into Human equivalent dose $(\mathrm{HED})=30 \times 0.162=4.86 \mathrm{mg} / \mathrm{kg}$.

Dose for $60 \mathrm{~kg}$ (Avg.) human $=4.86 \times 60=291.6 \mathrm{mg} /$ $60 \mathrm{~kg}$ man $\approx 300 \mathrm{mg} / 60 \mathrm{~kg}$.

According to product's regimen $=2$ Tab. TID (Wt. of Tab. is $500 \mathrm{mg}$ ), it means 6 tablets a day.

So, $50 \mathrm{mg} / \mathrm{kg}=75 \times 6=450 \mathrm{mg} \approx 500 \mathrm{mg} / 60 \mathrm{~kg} /$ day. $100 \mathrm{mg} / \mathrm{kg}=150 \times 6=900 \mathrm{mg} \approx 1000 \mathrm{mg} / 60 \mathrm{~kg} /$ day. $200 \mathrm{mg} / \mathrm{kg}=300 \times 6=1800 \mathrm{mg} \approx 2000 \mathrm{mg} / 60 \mathrm{~kg} /$ day. The clinically used dose i.e. $3 \mathrm{~g}$ doesn't appear to be safe. As from our study it was seen that the 
Table 7 Human equivalent dose calculation based on body surface area

\begin{tabular}{|c|c|c|c|c|c|c|}
\hline \multirow[t]{2}{*}{ Species } & \multirow{2}{*}{$\begin{array}{l}\text { References body } \\
\text { weight }(\mathrm{kg})\end{array}$} & \multirow{2}{*}{$\begin{array}{l}\text { References body } \\
\text { range }(\mathrm{kg})\end{array}$} & \multirow{2}{*}{$\begin{array}{l}\text { Body surface } \\
\text { area }\left(\mathrm{m}^{2}\right)\end{array}$} & \multirow{2}{*}{$\begin{array}{l}\text { To convert dose in } \\
\mathrm{mg} / \mathrm{kg} \text { to dose in } \\
\mathrm{mg} / \mathrm{m}^{2} \text {, multiply by } \mathrm{K}_{\mathrm{m}}\end{array}$} & \multicolumn{2}{|c|}{ To convert animal dose in mg/kg, either } \\
\hline & & & & & Divide animal dose by & Divide animal dose by \\
\hline Human & 60 & - & 1.62 & 37 & - & - \\
\hline Mouse & 0.02 & $0.011-0.3034$ & 0.007 & 3 & 12.3 & 0.081 \\
\hline Hamster & 0.08 & $0.047-0.157$ & 0.016 & 5 & 7.4 & 0.135 \\
\hline Rat & 0.15 & $0.08-0.27$ & 0.025 & 6 & 6.2 & 0.162 \\
\hline Ferret & 0.20 & $0.16-0.54$ & 0.043 & 7 & 5.3 & 0.189 \\
\hline Guinea pig & 0.40 & $0.208-0.700$ & 0.05 & 8 & 4.6 & 0.216 \\
\hline Rabbit & 1.8 & $0.90-3.0$ & 0.15 & 12 & 3.1 & 0.324 \\
\hline Dog & 10 & $5-17$ & 0.50 & 20 & 1.8 & 0.541 \\
\hline Monkey (rhesus) & 3 & $1.4-4.9$ & 0.25 & 12 & 3.1 & 0.324 \\
\hline Marmoset & 0.35 & $0.14-0.72$ & 0.06 & 6 & 6.2 & 0.162 \\
\hline Squirrel monkey & 0.60 & $0.29-0.97$ & 0.09 & 7 & 5.3 & 0.189 \\
\hline Baboon & 12 & $7-23$ & 0.60 & 20 & 1.8 & 0.541 \\
\hline Macro pig & 20 & $10-23$ & 0.74 & 27 & 1.4 & 0.730 \\
\hline Mini pig & 40 & 25.64 & 1.14 & 35 & 1.1 & 0.946 \\
\hline
\end{tabular}

${ }^{a}$ Data obtained from FDA draft guidelines. ${ }^{[7]}$ FDA: Food and Drug Admin istration, HED: Human equivalent dose

margin of safety is narrow that's why the conclusion was made to prescribe $100 \mathrm{mg} / \mathrm{kg}$ cautiously to the patients unless otherwise the therapy should be continued with $50 \mathrm{mg} / \mathrm{kg}$.

\section{Additional file}

Additional file 1: Historical Control Ranges for Selected Clinical Chemestry Parameters in Laboratory Animals. (JPEG 143 kb)

\section{Abbreviations}

ALT: Alanine transaminase; AST: Aspartate transaminase; CKD: Chronic kidney disease; EDTA: Ethylenediamine tetra acetate; ESRD: End stage renal disease; h: hour; Hb: Hemoglobin; HCT: Hematocrit; HDL: High density lipoprotein; HED: Human equivalent dose.; hrs.: hours; HSC: Hepatic stellate cells; $\mathrm{LD}_{50}$ : Lethal dose; $\mathrm{MCH}$ : Mean cell hemoglobin; MCHC: Mean cell hemoglobin concentration; MCV: Mean corpuscular volume; NOEL: Non observable effect level; p.o.: Per-oral; PLT: Platelet; RBCs: Red blood cells; TG: Triglycerides; VLDL: Very low density lipoprotein; WBCs: White blood cells

\section{Acknowledgements}

We are grateful to the Punjab University College of Pharmacy for providing us the facilities to carry out the work in the efficient way.

\section{Funding}

The present research was funded by University of the Punjab, Lahore Paksitan under grant no. PU/Ref./007-15.

\section{Availability of data and materials}

All data generated or analyzed during this study are included in this published article.

\section{Authors' contributions}

Saiqa Ishtiaq and Maida Akram conceived the idea and planed the research design. Sairah Hafeez Kamran and Muhammad Shaharyar Khan Afridi, assisted the research design, interpreted the results, drafted the manuscript and handled the reviewer's comments. Uzma Hanif, Shehla Akbar and Ayesha Asif assisted to conduct the research work. Sajid-ur-Rehman, M. Younas Khan and Atika Afzal performed the histopathological assessment of liver and kidney tissue. All authors reviewed, read and approved the final manuscript.

Ethics approval and consent to participate

Consent of participation is not aplicable for our manuscript. However, the protocol used for animal model data in this study was approved by the Animal Ethical Committee of Punjab University College of Pharmacy, University of the Punjab (AEC/UCP 1043), prepared by National Institute of Health.

Consent for publication

The University of the Punjab has consented for the publication.

\section{Competing interests}

The authors declare that they have no competing interests.

\section{Publisher's Note}

Springer Nature remains neutral with regard to jurisdictional claims in published maps and institutional affiliations.

\section{Author details}

${ }^{1}$ Punjab University College of Pharmacy, University of the Punjab Allama labal Campus, Lahore 54000, Pakistan. ²Department of Botany, Government College University, Lahore, Pakistan. ${ }^{3}$ Department of Pharmacy, Islamia University of Bahawalpur, Bahawalpur, Pakistan. ${ }^{4}$ Department of Pharmacy, Hajvery University, Lahore, Pakistan. ${ }^{5}$ Lahore College of Pharmaceutical Sciences, Lahore, Pakistan.

Received: 5 December 2016 Accepted: 23 July 2017

Published online: 04 August 2017

\section{References}

1. Benzie IF, Wachtel-Galor S. (Eds.). Herbal medicine: biomolecular and clinical aspects. CRC Press, 2011.

2. Foreword HD. In PDR for herbal medicines. 4th ed. Montvale: N. J., Thomson Health care Inc; 2007.

3. Kumaran RS, Jung $\mathrm{H}$, Kim HJ. In vitro screening of taxol, an anticancer drug produced by the fungus, Colletotrichum capsici. Engin Life Sci. 2011;11(3):264-71. 
4. Schümann J, Prockl J, Kiemer AK, Vollmar AM, Bang R, Tiegs G. Silibinin protects mice from $T$ cell-dependent liver injury $\_$. J Hepatol. 2003;39(3):333-40

5. Barnes J, Anderson LA, Phillipson JD. Herbal medicines: a guide for healthcare professionals: pharmaceutical press, 2003.

6. Wambebe C. Development of standardized phytomedicines in Africa. J Pharm Res Dev. 1998;3:1-11.

7. Bent S. Herbal medicine in the United States: review of efficacy, safety, and regulation: grand rounds at University of California, san Francisco medical center. J General Intern Med. 2008;23(6):854-9.

8. Gurib-Fakim A. Medicinal plants: traditions of yesterday and drugs of tomorrow. Mol Asp Med. 2006;27(1):1-93.

9. Brevoort P. The blooming U.S. botanical market: a new overview. HerbalGram 1998; 44: 33-46.

10. Seo Bl, Lee JH, Choi HY, Gwon DR, Boo YM. Herbology of oriental medicine. Seoul: Younglimsa. 2004:724-6.

11. Lee SI. Herbology. Seoul: Suseowon; 1981. p. 101-2.

12. Kiyohara H, Matsumoto T, Yamada H. Combination effects of herbs in a multi-herbal formula: expression of Juzen-taiho-to's immuno-modulatory activity on the intestinal immune system. Evidence-Based Complement Altern Med. 2004;1(1):83-91.

13. Joshi CS, Priya ES, Venkataraman S. Acute and subacute toxicity studies on the polyherbal antidiabetic formulation Diakyur in experimental animal models. J Health Sci. 2007;53(2):245-9.

14. Shin IS, Lee MY, Kim Y, Seo CS, Kim JH, Shin HK. Subacute toxicity and stability of Soshiho-tang, a traditional herbal formula, in Sprague-Dawley rats. BMC Complement Altern Med. 2012;12(1):266.

15. Schulz V, Hänsel R, Tyler VE Rational phytotherapy: a physician's guide to herbal medicine. Psychology Press. 2001; p. 21

16. Adewunmi CO, Ojewole JAO. Safety of traditional medicines, complementary and alternative medicines in Africa. Afr J Tradit Complement Altern Med. 2004;1:1-3.

17. Adeyemi OO, Akindele AJ, Nwumeh KI. Acute and subchronic toxicological assessment of Byrsocarpus coccineus Schum. And Thonn. (Connaraceae) aqueous leaf extract. Int J Appl Res Nat Prod. 2010;3(2):1-11.

18. Pakistan: Qarshi; Available from: http://qarshi.com/product/hab-e-kabadnoshadri/, Retrieved on: April 19, 2017.

19. Balogun FO, Tom Ashafa AO. Acute and Subchronic Oral Toxicity Evaluation of Aqueous Root Extract of Dicoma anomala Sond. in Wistar Rats. EvidenceBased Complemen Altern Med. 2016

20. Afolabi SO, Akindele AJ, Awodele O, Anunobi CC, Adeyemi OO. A 90 day chronic toxicity study of Nigerian herbal preparation DAS-77 in rats. BMC Complement Altern Med. 2012;12(1):79.

21. Galigher AE, Kozloff EN. Essentials of Practical Microtechniques. $2^{\text {nd }}$ edn Philadelphia: Lea and Febiger. 1971; p. 77.

22. Habbu PV, Shastry RA, Mahadevan KM, Joshi H, Das SK. Hepatoprotective and antioxidant effects of Argyreia speciosa in rats. Afri J Tradit Complement Altern Med. 2008;5:158-64.

23. Jacobson-Kram D, Keller KA. (Eds). Toxicological Testing Handbook: Principles, Applications and Data Interpretation. 2006. CRC Press.

24. Sushruta K, Satyanarayana S, Srinivas S, Sekhar JR. Evaluation of the bloodglucose reducing effects of aqueous extracts of the selected umbelliferous fruits used in culinary practices. Trop J Pharm Res. 2007;5(2):613-7.

25. Harish G, Danapur V, Jain R, Patell VM. Endangered medicinal plant Embelia ribes Burm. F.-a review. Pharmacog J. 2012;4(27):6-19.

26. Shanmugasundram R, Devi VK, Tresina PS, Maruthupandian A, Mohan VR. hepatoprotective activity of ethanol extract of Clitoria ternatea L. and Cassia angustofolia vahl leafs against $\mathrm{CCl}_{4}$ induced liver toxicity in rats. Int Res $\mathrm{J}$ Pharm. 2010:201-5.

27. Koo Y-C, Hong C-O, Nam M-H, Kim JH, Yang S-Y, Won N-H, et al. Inhibitory effect of yellow myrobalan (Terminalia chebula) extract on fibrosis induced by carbon tetrachloride in rat liver. Food Sci Biotechnol. 2013;22(3):871-80

28. Ullah HA, Zaman S, Juhara F, Akter L, Tareq SM, Masum EH, Bhattacharjee R. Evaluation of antinociceptive, in-vivo \& in-vitro anti-inflammatory activity of ethanolic extract of Curcuma zedoaria rhizome. BMC Complement Altern Med. 2014;14(1):1.

29. Jeena K, Liju VB, Kuttan R. Antioxidant, anti-inflammatory and antinociceptive activities of essential oil from ginger. Indian J Physiol Pharmacol. 2013;57(1):51-62.
30. Hadisaputri YE, Miyazaki T, Suzuki S, Kubo N, Zuhrotun A, Yokobori T,. Kuwano $\mathrm{H}$. Molecular characterization of antitumor effects of the rhizome extract from Curcuma zedoaria on human esophageal carcinoma cells. Int J Oncol 2015; 47(6): 2255-2263.

31. Thomson M, Al-Qattan K, Al-Sawan S, Alnaqeeb M, Khan I, Ali M. The use of ginger (Zingiber Officinale Rosc.) as a potential anti-inflammatory and antithrombotic agent. Prostaglandins, Leukot Essent Fatty Acids. 2002;67(6):475-8.

32. Maity TK, Mandal SC, Mukherjee PK, Saha K, Das J, Pal M, Saha B. Studies on antiinflammatory effect of Cassia tora leaf extract (fam. Leguminosae). Phytother Res. 1998;12(3):221-3.

33. Rajalakshmi M, Sales MS. Antioxidant potentials of active principles from Terminalia bellarica fruit-an in-vitro and in-vivo approach. World J Pharm Pharm Sci. 2015;4(4):1301-14.

34. Hala MA. Comparative antioxidant activity study of some edible plants used spices in Egypt. J American Sci. 2011;7(1):1118-22.

35. Kim S.-H, Jun C.-D, Suk K, Choi B.-J, Lim H, Park S,... Shin T.-Y. Gallic acid inhibits histamine release and pro-inflammatory cytokine production in mast cells. Toxicol Sci 2006; 91(1): 123-131.

36. Doucette CD, Rodgers G, Liwski RS, Hoskin DW. Piperine from black pepper inhibits activation-induced proliferation and effector function of $T$ lymphocytes. J Cell Biochem. 2015:116(11):2577-88.

37. Mishra V, Agrawal M, Onasanwo SA, Madhur G, Rastogi P, Pandey HP... . Narender T. Anti-secretory and cyto-protective effects of chebulinic acid isolated from the fruits of Terminalia chebula on gastric ulcers. Phytomed 2013; 20(6): 506-511.

38. Bhandari U, Kanojia R, Pillai K. Effect of ethanolic extract of Embelia ribes on dyslipidemia in diabetic rats. J Diabetes Res. 2002;3(3):159-62.

39. Latha RCR, Daisy P. Therapeutic potential of octyl gallate isolated from fruits of Terminalia bellerica in streptozotocin-induced diabetic rats. Pharm Biol. 2013;51(6):798-805.

40. Mammen EF. Coagulation abnormalities in liver disease. Hematology/ oncology clinics of North America. 1992;6(6):1247-57.

41. Amitrano L, Guardascione MA, Brancaccio V, Balzano A. Coagulation disorders in liver disease. In Seminars in liver disease. 2002; 22(1): 83-96. Thieme Medical Publishers, Inc., New York.

42. Bosch J, García-Pagán JC. Complications of cirrhosis. I Portal hypertension. J Hepatol. 2000;32:141-56.

43. Kaw D, Malhotra D. Hematology: issues in the dialysis patient: platelet dysfunction and end-stage renal disease. Semin Dial. 2006;19(4):317-22.

44. Nair $A B$, Jacob $S$. A simple practice guide for dose conversion between animals and human. J Basic Clin Pharm. 2016;7(2):27-31.

\section{Submit your next manuscript to BioMed Central and we will help you at every step:}

- We accept pre-submission inquiries

- Our selector tool helps you to find the most relevant journal

- We provide round the clock customer support

- Convenient online submission

- Thorough peer review

- Inclusion in PubMed and all major indexing services

- Maximum visibility for your research

Submit your manuscript at www.biomedcentral.com/submit 